\title{
Charlie Hebdo E Islamofobia
}

Francirosy Campos Barbosa ${ }^{1}$

Tudo que envolve muçulmanos na contemporaneidade ganha destaque na mídia. Muçulmanos não passam mais desapercebidos desde o 11/09. 0 que certamente amplia significativamente os estereótipos que já eram propagados, basta ler os textos de Edward Said, para compreender que o Oriente islâmico sempre foi contemplado com estereótipos que não representam a verdadeira imagem dos "representados".

Pontuo como antropóloga a necessidade do relativismo cultural, que é a desconstrução do "certo" e "errado", pois isto depende de qual contexto nós estamos nos remetendo. É preciso verificar qual o grau de tolerância se tem em relação a algumas imagens e como elas são propagadas. Se no Islam $^{2}$ não se reproduz a imagem dos Profetas, pois se considera isto inadequado dentro dos preceitos religiosos, imaginem quando essas imagens são reproduzidas como "chacota"; humilhação do grupo (Ferreira, 2006). O que está faltando? Talvez a resposta mais rápida seja: falta diálogo! Neste sentido, os muçulmanos terão que ser mais propositivos em tentar ensinar ao Ocidente do que se trata o Islam, e não bastam discursos religiosos. É preciso ocupar o espaço público/político de forma positiva, fazer com que a sociedade veja quem são os muçulmanos e no que eles acreditam.

Enquanto os muçulmanos estiverem escrevendo e falando para eles mesmos, a mensagem não será comunicada. É preciso sair da defensiva e "contra-atacar" com um discurso que o ocidente compreenda. Talvez falte, e aí, o ponto pode ser interessante, falte mais intelectuais muçulmanos comprometidos em desconstruir a imagem que os ocidentais fazem do Islam e dos muçulmanos e falta, sobretudo diálogo e ação política.

\footnotetext{
1 Antropóloga, docente do Departamento de Psicologia, FFCLRP/USP, Universidade de São Paulo, coordenadora do GRACIAS - Grupo de Antropologia em Contextos Islâmicos e Árabes. Email: franci@ffclrp.usp.br

${ }^{2}$ A forma gráfica Islam e não Islã, como costumeiramente se escreve em português, é uma escolha de tradução da autora.
} 
Não basta dizer que seguem o Alcorão e a Sunnah do Profeta Muhammad, é preciso muito mais que discursos, é preciso criar o contradiscurso daquilo que está na mídia. O não diálogo, levará certamente a outros riscos e não promove nem o Islam, muito menos a desconstrução etnocêntrica que a Europa se encontra desde os primórdios. O Islam não é a religião do Oriente, é sim, a religião pautada na universalidade, basta ler o último discurso do Profeta Muhammad antes de sua morte... a religião é dos árabes e dos não-árabes, portanto é de todos e para todos.

Tariq Ramadan em entrevista à BBC diz:

\begin{abstract}
We need to have an overall vision of what is happening around the world, and for us - you as a British citizen and me as a Swiss citizen, and as European citizens - we have to come together and to say [that] as much as we are condemning what is happening here, the value of lives in Iraq or in Syria or around the world, in Palestine or wherever, in Africa, have the same value as our lives. And we have to ask our governments for consistency, and then to come to social policy when it comes to equal citizenship to act against racism and anti-Semitism and anti-Islam... I think there is a lack of consistency even in our emotional reactions to the death of people.
\end{abstract}

Não é o Islam que deve ser criticado, não se trata de colocar em cheque a religião e, sim, o comportamento de alguns muçulmanos. Muçulmanos tolerantes, que promovem o diálogo são muitos, mas infelizmente, apenas uma pequena parcela ganha as mídias, mais do que aqueles que tem real conhecimento e vivem a religião de forma ímpar e singular.

De modo geral, os críticos do Islam são aqueles que não conhecem a religião. As pessoas estão presas a estereótipos e sinais diacríticos, como o véu islâmico e o associam à opressão, assim como, o uso do 'turbante" aos "Sheiks do petróleo", enfim, constroem-se imagens equivocadas dos significados simbólicos dos paramentos religiosos.

As restrições às imagens têm relação direta a Tawhid ${ }^{3}$ impossibilitando qualquer tipo de associação com imagens e objetos. Sendo a recordação de Deus o que há de mais importante no Islam. Por isso, o cuidado de não se associar a Ele imagens é fundamental. Recorda-se Deus não por imagens, mas pelas recitações: “Allahu Akbar" (Deus é Maior); SubhanAllah (Deus seja louvado) etc.

\footnotetext{
3 Tawhid significa unicidade. Acreditar na Tawhid no Islam é dizer que só Deus é soberano.
} 
Que são fiéis e cujos corações sossegam com a recordação de Deus. Não é, acaso, certo, que à recordação de Deus sossegam os corações? (13:28)

Neste versículo do Alcorão é possível compreender que o Islam está centrado na recordação de Deus, quem o recorda constantemente tem seu coração sossegado, sabe que está na "senda reta" e que só Ele é capaz de mudar o destino prescrito.

O que vimos no episódio triste do Charlie Hebdo foi reflexo da intolerância, da falta de diálogo e da compreensão dos preceitos islâmicos, por outro lado, nada justifica a violência cometida por "ditos muçulmanos" em nome do Islam. Em nome do Islam se prega a paz e não a violência. A própria palavra Islam significa Paz, o cumprimento entre os muçulmanos é Assalamu Aleikum, "que a paz esteja com você". É preciso que ocidentais quebrem o etnocentrismo e o discurso islamofóbico. Fazer com que o diálogo coloque em pauta as diferenças, sem que as agressões sejam as respostas concedidas.

É certo pontuar que a França e vários países da Europa vem sistematicamente banindo os imigrantes do seu território, elaborando leis mais rígidas para não aceitação do diferente, com a desculpa da laicidade francesa, tem-se construído um tipo de "laicidade" que exclui o outro, o diferente, contrapondo-se ao próprio significado que é o diálogo entre as diversas denominações religiosas sem que uma se sobreponha a outra.

A crítica infundada aos muçulmanos leva a intolerância religiosa e étnica de grupos que já vivem na periferia de Paris e vivem à margem da sociedade europeia/francesa, aqui destacamos os casos dos argelinos, mesmo sendo, famílias que estejam na terceira e quarta geração, isto significa, que são franceses, ainda assim, são excluídos do convívio da sociedade.

Considero fundamental reacender o debate, pois, enquanto não se pensarem estratégias de diálogo, seja via educação, promoção de eventos e debates, conviveremos com o desgaste constante da não aceitação de um lado e de outro. A religião não pode ser imposta, mas a política de exclusão também não. 


\section{Referências}

FERREIRA, Francirosy, Campos Barbosa. Imagem Oculta- reflexões sobre a relação dos muçulmanos com as imagens fotográficas. PPGAS, USP, 2001.

FERREIRA, Francirosy Campos Barbosa. A imagem do profeta - Proibir por quê? Cadernos de Antropologia e Imagem (UERJ), v. 22, p. 95-111, 2006.

FERREIRA, Francirosy Campos Barbosa. Abelhas, aranhas e pássaros: imagens islâmicas em movimento. In: Andrea Barbosa; Edgar Teodoro da Cunha; Rose Satiko Hikiji. (Org.). Imagem e Conhecimento. 1a.ed.Campinas: Papirus, 2009, v. , p. 199-226.

SAID, Edward. Orientalismo - A invenção do Oriente pelo Ocidente. São Paulo: Companhia das Letras, 2000. 